\title{
THE ROLE OF ORGANIZATIONAL CULTURE AND MOTIVATION IN MEDIATING LEADERSHIP STYLE RELATIONSHIPS TO EMPLOYEE PERFORMANCE
}

\author{
Rio Bernath Pardede ${ }^{1}$, Bambang Satriawan ${ }^{2}$ Indrayani $^{3}$, Chablullah Wisbisono ${ }^{4}$ \\ 1,2,3,4 Department of Management Master Program Batam University, Indonesia \\ Correspondence Address: Jl. Abdulyatama No 5, Batam, Kepulauan Riau. \\ E-mail: ${ }^{1)}$ riokphlbatam@gmail.com
}

\begin{abstract}
This study aims to see the influence of leadership style on the performance of employees in the Department of Environment and Forestry of Riau Islands Province by mediated by organizational culture and motivation. This study is a quantitative study that uses a sample of 63 respondents. Data analysis in this study uses Structural Equation Modeling (SEM) analysis to confirm the dimensions of the concept created and measure how much influence independent variables have on dependent variables. The results showed that: (1) Leadership Style has a positive and significant effect on organizational culture, (2) Leadership Style has a positive and significant effect on employee work motivation, (3) Leadership style has a positive and significant effect on employee performance, (4) Culture does not have a positive and significant effect on employee performance, (5) Motivation positively and significantly affects employee performance, (6) Leadership style affects performance mediated by organizational culture, (7) Leadership style influences performance mediated by work motivation, (8) Organizational culture has a positive and significant effect on work motivation.
\end{abstract}

Keywords: Leadership style, Culture, Motivation, Performance

\section{INTRODUCTION}

To support the achievement of organizational goals, not only have human resources in quantity, but the achievement of the goals of the organization is highly dependent on the performance of human resources in it, or it can be said that the achievement of organizational goals must also be supported by human resources in quality. The performance of employees in an organization can certainly not be obtained, but several factors can influence, among others, the Leadership Style. In optimizing the functioning of human resources in an organization, a leader must have the right way and style of leadership, so that the policies taken have the full support of all lines of the organization and can be executed under the strategies set in achieving the goals of the organization.

Susanto (2011) in Edison (2016) suggests that organizational culture is a pattern of shared beliefs, behaviours, assumptions, and values. Organizational culture shapes how organization members behave and interact and influences how they work. In turn, the culture of this organization is expected to create an environment conducive to improving the performance of individuals and organizations. Besides, motivation is another factor of leadership style, organizational culture, and performance inherent in employees to be able to carry out tasks well and improve the quality of work at all times. According to Malayu (2005), motivation is the encouragement or provision of the driving force that creates the excitement of one's work so that they want to cooperate, work effectively and integrated with all their efforts to achieve satisfaction. This statement can also be interpreted that motivation is an attraction that arises from within the employee itself which results in the intention to have a good performance. According to Mathis (2001), motivation is a desire within a person that causes the person to take action. While Rivai 
(2004) argues that motivation is a series of attitudes and values that influence individuals to achieve specific things according to individual goals. Motivation is the willingness to make highlevel efforts to achieve organizational goals conditioned by the ability of the business to satisfy the needs of many individuals (Robins and Mary, 2005). Motivation is a psychological factor that shows an individual's interest in work, complacency and responsibility for the activities or work carried out (Masrukhin and Waridin, 2004).

Performance according to Efendi (2002:548) is a function of motivation and the ability to complete a person's task or work should have a certain degree of willingness and level of ability. One's skills and skills are not effective enough to do something without a clear understanding of what it will do and how to do it. While performance according to Mangkunegara (2008:67) the results of work in quality and quantity achieved by an employee in carrying out his duties by the responsibilities given to him.

\section{IMPLEMENTATION METHOD}

Research methods can be grouped into experimental, survey and naturalistic research methods (Sugiyono, 2016). In this study, researchers used a survey method that is to get data from a certain natural place (not artificial), but researchers conduct treatment in data collection, for example by circulating questionnaires, tests, structured interviews and so on. The research and samples in this study are civil servants in the Department of Environment and Forestry of Riau Islands Province numbered 63 people. This research uses Structural Equation Modeling (SEM) technique with the help of Smart PLS 2.0 M3 software.

\section{RESULTS AND DISCUSSION}

Data processing using Partial Least Square (PLS) based Structure Equation Modelling (SEM) method requires two stages to assess the Fit Model of a research model (Ghozali, 2008). The first stage is to assess the outer model or measurement model by looking at the value of Convergent Validity, Discriminant Validity and Composite Reliability.

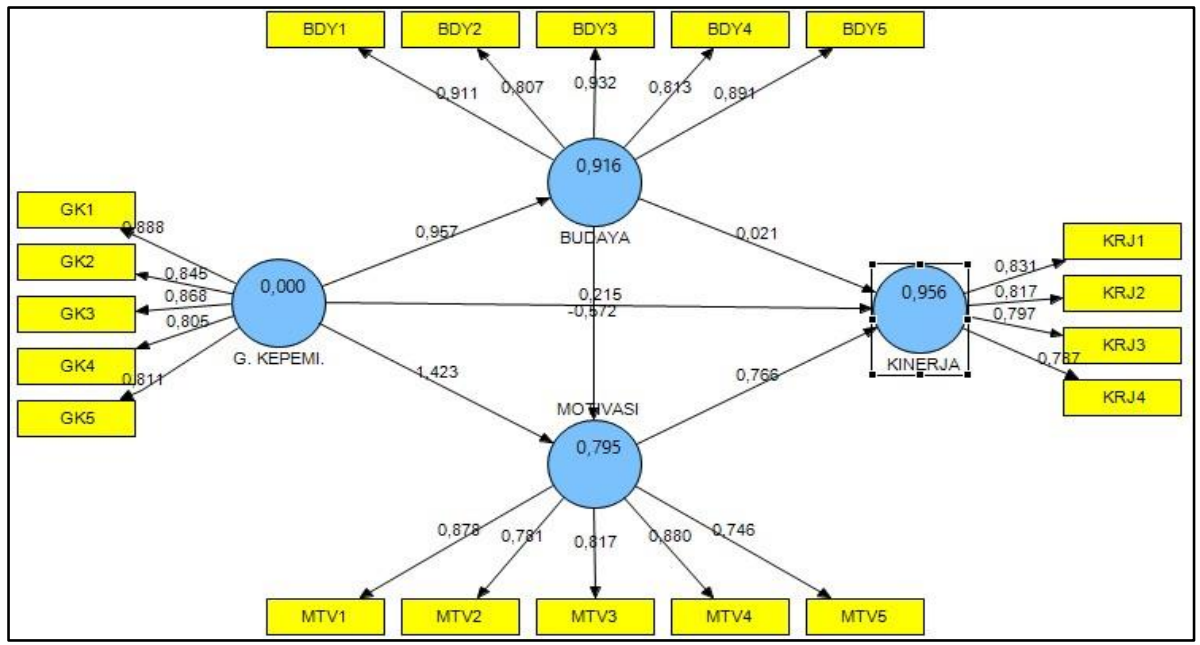




\subsection{Validity test}

Validity test is conducted in two stages, namely convergent validity test with validity test based on factor loading value and phase two through discriminant validity test with validity test based on how to compare loading value on the intended construct should be greater compared to other construct loading values.

a. Convergent validity

Table 1. Value Loading Factor Variable Leadership Style

\begin{tabular}{|c|c|c|c|c|}
\hline \multirow{4}{*}{ Variable } & Indicator & $\begin{array}{c}\text { Outer Loading } \\
\text { Value }\end{array}$ & Standart Value & Descrintion \\
\hline \multirow{4}{*}{$\begin{array}{c}\text { Gaya } \\
\text { Kepemimpinan }\end{array}$} & GK1 & 0,888283 & $>0,6$ & Valid \\
\cline { 2 - 5 } & GK2 & 0,844870 & $>0,6$ & Valid \\
\cline { 2 - 5 } & GK3 & 0,867809 & $>0,6$ & Valid \\
\cline { 2 - 5 } & GK4 & 0,804694 & $>0,6$ & Valid \\
\cline { 2 - 5 } & GK5 & 0,810811 & $>0,6$ & Valid \\
\hline
\end{tabular}

Table 2. Value Loading Factor Variable Motivation

\begin{tabular}{|c|c|c|c|c|}
\hline \multirow{4}{*}{ Variable } & Indicator & $\begin{array}{c}\text { Outer Loading } \\
\text { Value }\end{array}$ & $\begin{array}{c}\text { Standart Value } \\
\text { Descrintion }\end{array}$ \\
\hline \multirow{4}{*}{ Motivasi } & MTV1 & 0,878225 & $>0,6$ & Valid \\
\cline { 2 - 5 } & MTV2 & 0,780903 & $>0,6$ & Valid \\
\cline { 2 - 5 } & MTV3 & 0,817157 & $>0,6$ & Valid \\
\cline { 2 - 5 } & MTV4 & 0,880103 & $>0,6$ & Valid \\
\cline { 2 - 5 } & MTV5 & 0,746326 & $>0,6$ & Valid \\
\hline
\end{tabular}

Table 3. Value Loading Factor Variable Job Satisfaction

\begin{tabular}{|c|c|c|c|c|}
\hline \multirow{4}{*}{ Variable } & Indicator & $\begin{array}{c}\text { Outer Loading } \\
\text { Value }\end{array}$ & $\begin{array}{c}\text { Standart Value } \\
\text { Descrintion }\end{array}$ \\
\hline \multirow{4}{*}{ Budaya Organisasi } & BDY1 & 0,911070 & $>0,6$ & Valid \\
\cline { 2 - 5 } & BDY2 & 0,807003 & $>0,6$ & Valid \\
\cline { 2 - 5 } & BDY3 & 0,931960 & $>0,6$ & Valid \\
\cline { 2 - 5 } & BDY4 & 0,812582 & $>0,6$ & Valid \\
\hline
\end{tabular}

Table 4. Performance Variable Loading Factor Value

\begin{tabular}{|c|c|c|c|c|}
\hline \multirow{3}{*}{ Variable } & Indicator & $\begin{array}{c}\text { Outer Loading } \\
\text { Value }\end{array}$ & Standart Value & Descriotion \\
\hline \multirow{3}{*}{ Kinerja } & KRJ1 & 0,831300 & $>0,6$ & Valid \\
\cline { 2 - 5 } & KRJ2 & 0,816619 & $>0,6$ & Valid \\
\cline { 2 - 5 } & KRJ3 & 0,796715 & $>0,6$ & Valid \\
\cline { 2 - 5 } & KRJ4 & 0,787125 & $>0,6$ & Valid \\
\hline
\end{tabular}

Based on the table above, it can be seen that the results of the data processing using the SmartPLS 2.0 method, all loading factor values of the indicators used in this study are valid or have met the convergent validity. Of each of these indicators is worth more than 0.6 so all indicators are valid indicators to measure the construct.

b. Discriminant validity

Discriminant validity test is this value is a cross loading factor value that is useful to know if the construct has an adequate discriminant value by comparing the loading value on the intended construct should be greater than the loading value with other constructions (Hussein, 2015). 
THE ROLE OF ORGANIZATIONAL CULTURE AND MOTIVATION IN MEDIATING LEADERSHIP STYLE RELATIONSHIPS TO EMPLOYEE PERFORMANCE

DOI: https://doi.org/10.54443/ijset.v1i2.13

Table 5. Variable Cross Loading Value

\begin{tabular}{|c|c|c|c|c|}
\hline & Budava & $\begin{array}{c}\text { Gaya } \\
\text { Kenemimninan }\end{array}$ & Kineria & Motivas \\
\hline BDY1 & $\mathbf{0 , 9 1 1 0 7 0}$ & 0,867809 & 0,787125 & 0,682106 \\
\hline BDY2 & $\mathbf{0 , 8 0 7 0 0 3}$ & 0,788575 & 0,662907 & 0,572393 \\
\hline BDY3 & $\mathbf{0 , 9 3 1 9 6 0}$ & 0,856632 & 0,739861 & 0,706770 \\
\hline BDY4 & $\mathbf{0 , 8 1 2 5 8 2}$ & 0,763645 & 0,699348 & 0,690227 \\
\hline BDY5 & $\mathbf{0 , 8 9 0 7 1 1}$ & 0,888283 & 0,731670 & 0,780903 \\
\hline GK1 & 0,890711 & $\mathbf{0 , 8 8 8 2 8 3}$ & 0,731670 & 0,780903 \\
\hline GK2 & 0,771365 & $\mathbf{0 , 8 4 4 8 7 0}$ & 0,786764 & 0,822561 \\
\hline GK3 & 0,911070 & $\mathbf{0 , 8 6 7 8 0 9}$ & 0,787125 & 0,682106 \\
\hline GK4 & 0,804373 & $\mathbf{0 , 8 0 4 6 9 4}$ & 0,687225 & 0,586890 \\
\hline GK5 & 0,655533 & $\mathbf{0 , 8 1 0 8 1 1}$ & 0,826868 & 0,811906 \\
\hline KRJ1 & 0,660473 & 0,816018 & $\mathbf{0 , 8 3 1 3 0 0}$ & 0,817157 \\
\hline KRJ2 & 0,511869 & 0,609684 & $\mathbf{0 , 8 1 6 6 1 9}$ & 0,880103 \\
\hline KRJ3 & 0,627894 & 0,642244 & $\mathbf{0 , 7 9 6 7 1 5}$ & 0,746326 \\
\hline KRJ4 & 0,911070 & 0,867809 & $\mathbf{0 , 7 8 7 1 2 5}$ & 0,682106 \\
\hline MTV1 & 0,526093 & 0,603944 & 0,803672 & $\mathbf{0 , 8 7 8 2 2 5}$ \\
\hline
\end{tabular}

From Table 5, it is seen that the correlation value of the construct with its indicator is greater than the correlation value with other constructs. From the results of the data using smartPLS 2.0, that can be concluded all latent constructs leadership style (X1), Organizational culture (X2), work discipline (X3), and Performance (Y) shows a good discriminant validity because it can predict indicators on their blocks better than indicators on other blocks. Furthermore, the discriminant validity test is done by looking at the AVE (Average Variance Extracted) value. AVE value is good if it has a value greater than 0.50 (Gozali \& Latan, 2015). The following is shown the AVE value in Table 5 below:

Table 6. Average Variance Extracted (AVE) Research Model

\begin{tabular}{|c|c|c|}
\hline Variable & Standart & AVE Value \\
\hline Gaya Kepemimpinan & 0,5 & 0,712178 \\
\hline Budaya Organisasi & 0,5 & 0,760702 \\
\hline Motivasi & 0,5 & 0,676084 \\
\hline Kinerja & 0,5 & 0,653061 \\
\hline
\end{tabular}

Table 6 shows the AVE value of the research model for all research variables has been valued above 0.5 , so the AVE value for discriminant validity testing is already met for further testing. Therefore, from the test results through stage one covergent validity and phase two discriminant validity has been fulfilled so that this research model has been valid.

\subsection{Reliability test}

Reliability test is a reliability test that aims to know how far the measuring instrument can be relied on or trusted. Reliability indicators in this study are determined from composite reliability values and cronbach's alpha for each indicator block. 
a. Composite Reliability

Reliablitas test with composite reliability that is data has a composite reliability value $>0.7$ has a high reliability value. Here are the results of data processing using SmartPLS 2.0 from composite reliability.

Table 7. Composite Reliability Value Of Research Model

\begin{tabular}{|c|c|c|c|}
\hline Variable & Composite Reliability & Standart & Description \\
\hline Gaya Kepemimpinan & 0,925116 & $>0,7$ & Reliable \\
\hline Budaya Organisasi & 0,940615 & $>0,7$ & Reliable \\
\hline Motivasi & 0,912227 & $>0,7$ & Reliable \\
\hline Kinerja & 0,882712 & $>0,7$ & Reliable \\
\hline
\end{tabular}

Based on Table 7, it is the composite reliability value of the research model that shows that each variable has a composite reliability value above 0.7 with the lowest value of 0.882712 of the Performance variable (Y) and the highest value of 0.940615 of the Organizational Culture variable (X2). from the results of the data processing, that the research model has met the value of composite reliability and high-reliability test or reliable.

b. Cronbach's Alpha

The next stage of testing for reliabiltas is testing with cronbach's alpha value. This reliability test is reinforced by cronbach's alpha and the expected value is $>0.6$ for all constructs (Hussein, 2015). Here are the results of the data processing for cronbach's alpha value in the table below.

Table 8. Value Cronbach's Alpha Research Model

\begin{tabular}{|c|c|c|c|}
\hline Variable & Chronbach's Alpha & Standart & Description \\
\hline Gaya Kepemimpinan & 0,712178 & $>0,6$ & Reliable \\
\hline Budaya Organisasi & 0,760702 & $>0,6$ & Reliable \\
\hline Motivasi & 0,676084 & $>0,6$ & Reliable \\
\hline Kinerja & 0,653061 & $>0,6$ & Reliable \\
\hline
\end{tabular}

Based on the calculation of the data in Table 8 , Cronbach's alpha value from the research model shows that each variable has a > value of 0.6 with the lowest value on the Performance variable (Y) of 0.653 and the highest value in the Culture variable (X2) of 0.760 . From these results, this research model has fulfilled the value of Cronbach's alpha. The two stages of reliability testing with composite reliability and Cronbach's alpha shows that this research model has met the reliability criteria and is a reliable and reliable measuring instrument.

\subsection{Uji Hipotesis}

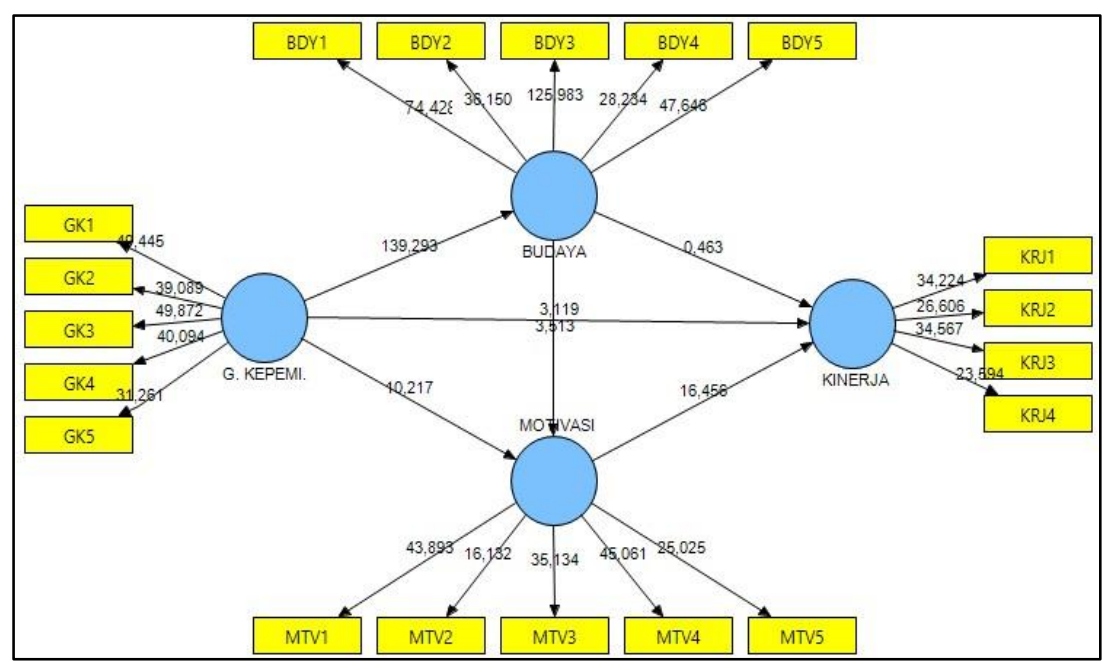

International Journal of Social Science, Educational, Economics, Agriculture Research, and Technology (IJSET) 


\section{DISCUSSION}

Based on the results of the hypothesis test in this study is: the first hypothesis, Leadership Style has a positive and significant effect on the culture of the organization in the office of the Department of Environment and Forestry of Riau Islands Province, seen from the value of $t$ values 139,293 far above the standard of 1.96. as for the value of the direct relationship between variables is 0.957 .

The second hypothesis, Leadership Style has a positive and significant effect on the work motivation of employees in the office of the Department of Environment and Forestry of Riau Islands Province with a value of $t$ values of 10,217 and the value of direct relationships between variables of 1,423 . This shows that leadership style plays a big role in motivating employees in the office of the Department of Environment and Forestry of Riau Islands Province.

The third hypothesis, Leadership style has a positive and significant effect on the performance of employees in the office of the Department of Environment and Forestry of Riau Islands Province with a value of $t$ values of 3,513. In this case, it can be explained that the leadership is a very strong influence in improving the performance of employees in the office of the Department of Environment and Forestry of Riau Islands Province.

The fourth hypothesis, Culture has no positive and significant effect on the performance of employees in the office of the Department of Environment and Forestry of Riau Islands Province with a value of $\mathrm{T}$ values of 0.463 . This explains that cultural variables do not play a role in improving the performance of employees in the office of the Department of Environment and Forestry of Riau Islands Province, while the value of direct relationships between variables is 0.957.

The fifth hypothesis, Motivation has a positive and significant effect on the performance of employees in the office of the Department of Environment and Forestry of Riau Islands Province with a value of $\mathrm{T}$ values of 16,456 while the value of direct relationships between variables is 0.766 . This explains that motivation plays a very important role in improving the performance of employees in the office of the Department of Environment and Forestry of Riau Islands Province.

The sixth hypothesis, leadership style affects the performance mediated by organizational culture with a value of $\mathrm{T}$ values of 139,756 , while the value of relationships between variables is 0.978. This can be explained that the culture of the organization is influential and plays an important role in connecting leadership styles to the performance of employees in the office of the Environment and Forestry Office of Riau Islands Province.

The seventh hypothesis, leadership style affects performance mediated by work motivation with a value of $T$ values of 26,673 , while the value of relationships between variables is 2,189 . This can be explained that work motivation is influential and plays an important role in connecting leadership styles to the performance of employees in the office of the Environment and Forestry Office of Riau Islands Province.

The eighth hypothesis, Organizational culture has a positive and significant effect on employee work motivation with a value of $\mathrm{T}$ values of $3,119(>1.96)$, while the value of relationships between variables is 0.215 . This explains that the role of culture is very large to the work motivation of employees in the office of the Department of Environment and Forestry of Riau Islands Province. 


\section{CONCLUSION}

1. The conclusion in this study is: the first hypothesis, Leadership Style has a positive and significant effect on the culture of the organization in the office of the Department of Environment and Forestry of Riau Islands Province, seen from the value of $t$ values 139,293 well above the standard of 1.96. The second hypothesis, Leadership Style has a positive and significant effect on the work motivation of employees in the office of the Department of Environment and Forestry of Riau Islands Province with a value of $t$ values of 10,217. The third hypothesis, Leadership style has a positive and significant effect on the performance of employees in the office of the Department of Environment and Forestry of Riau Islands Province with a value of $t$ values of 3,513. The fourth hypothesis, Culture has no positive and significant effect on the performance of employees in the office of the Department of Environment and Forestry of Riau Islands Province with a value of $T$ values of 0.463 . The fifth

2. hypothesis, Motivation has a positive and significant effect on the performance of employees in the office of the Department of Environment and Forestry of Riau Islands Province with a value of $\mathrm{T}$ values of 16,456. The sixth hypothesis, leadership style affects the performance mediated by organizational culture with a value of $\mathrm{T}$ values of 139,756. The seventh hypothesis, leadership style affects performance mediated by work motivation with a value of $T$ values of

3. 26,673. The eighth hypothesis, Organizational culture has a positive and significant effect on the work motivation of employees with a value of $t$ values of $3,119(>1.96)$.

\section{REFERENCES}

Edison, Emron, Yohny Anwar, \& Imas Komariyah. 2016. Manajemen Sumber Daya manusia. Bandung: Alfabeta.

Ghozali, Imam. 2016. Aplikasi Analisis Multivariat dengan Program IMB SPSS 23. Semarang: Universitas Diponegoro.

Ghozali, Imam, (2011). Structural Equation Modeling Metode Alternatif Dengan Partial Least Square (PLS) Edisi 3, Badan Penerbit Universitas Diponegoro. Semarang.

Hasibuan. Sp. Melayu. 2010. Manajemen Sumber Daya Manusia. Jakarta: Bumi Aksara. [5] . 2004. Manajemen Sumber Daya Manusia. Jakarta: Bumi Aksara.

Ilham, R. N., Erlina, K. A. F., Silalahi, A. S., Saputra, J., \& Albra, W. (2019). Investigation of the bitcoin effects on the country revenues via virtual tax transactions for purchasing management. Int. J Sup. Chain. Mgt Vol, 8(6), 737.

Ilham, R. N., Sinaga, S., Putri, D. E., Sinta, I., \& Fuadi, F. (2021). EFEK DARI LEVERAGE DAN UKURAN PERUSAHAAN DALAM MEMENGARUHI TINGKAT PROFITABILITAS. JURNAL ILMIAH EDUNOMIKA, 5(02).

Khaddafi, M., Subrata, H., Apriyanto, E., Iqbal, M., \& Darmawan, W. (2022). PENGENALAN DASAR PENGOPERASIAN KOMPUTER PADA ANAK USIA DINI. JATIMIKA: Jurnal Kreativitas Mahasiswa Informatika, 2(3).

Mangkunegara, Anwar Prabu. 2018. Pengertian dan Faktor Kinerja. Bandung : PT. Remaja Rosdakarya. 
Masrukin dan Waridin. 2004. Pengaruh Motivasi Kerja, Kepuasan Kerja, Budaya Organisasi Dan Kepemimpinan Terhadap Kinerja Pegawai. EKOBIS. Vol 7. No 2. Hal: 197-209.

Mathis, Robert L. \& John H. Jackson. 2006. (Human Resource Management) Manajemen Sumber Daya Manusia. Jakarta: Salemba Empat.

Rifai, Veithzal. 2004. Manajemen Sumber Daya Manusia Untuk Perusahaan. Jakarta: PT. RAJA GRAFINDO PERSADA.

Robbins, Stephen. P. Dan Mery Coulter. 2005. Manajemen. Jakarta: PT. INDEKS Kelompok Gramedia.

Sugiyono. 2016. Metode Penelitian manajemen. Bandung: Alfabeta.

Tegor, Dkk. (2020). Manajemen Sumber Daya Manusia. Yogyakarta : Penerbit Deepublish. 